\title{
Sanatın Ciddiyeti Üzerine: 17. Yüzyıl Hollanda Resim Sanatında Gülme Eylemi
}

\author{
Neslihan ÖZGENÇ *
}

Özet

Gülme eylemi, sadece neşe ve mutluluğu ifade etmez, diğer bir yanıyla alaycı bir tavrı da açığa çıkarır. Alaycı yıkıcılığından rahatsızlık duyulan gülme eylemi, tarih boyunca kontrol altına alınması gereken toplumsal bir durum olarak görülmüştür. İnançlar ile paralel gelişen Batı Sanatı da, Hıristiyan öğretilerinin davranışlara getirdiği yasaklar sonucunda, gülme eyleminin resmedilmesi karşısında ciddi bir tavır almıştır. Bu doğrultuda, dişleri göstererek sesli bir biçimde gülmenin sosyal statüyü aşağıya çekeceğine inanıldığından, resim siparişi veren bireylerin, ciddi görünümlü, sosyal statü ve zenginliklerini ifade edecek biçimde resmedildiği görülür. Fakat 17. yüzyıl Hollanda sanatında, diğer Avrupa Sanatı örneklerinden farklı olarak, köylü ve fakir halkı kahkaha atarken resmeden eserler görülmeye başlanmıştır. Bu çalışmanın amacı, Protestanlık sonrası 17. Yüzyıl Hollanda'sında ortaya çıkan yeni sanat türlerinin, gülme ve kahkahanın ironik durumunu ne şekilde ele aldığını ortaya koymaktır. Bu amaç doğrultusunda bu çalışmada, gülme eyleminin tarihsel süreci içinde sosyo-kültürel çözümlemeler yapılmış ve sonuç olarak gülme eyleminin sanattaki yerine dair genel tespitlerde bulunulmuştur.

Anahtar Sözcükler: Gülme, Kahkaha, Hollanda Sanatı, Kalvinizm, Tür Resmi.

\section{On Seriousness of Art: The Act of Laughing in the 17th Century Dutch Painting}

\begin{abstract}
Laughing reveals not only joy or happiness but it also reveals a cynical attitude. Because this cynical destructivism is nervewrecking, through history, laughing is treated as a social condition that needs to be under control. Western art, progressed parallel to beliefs, developed a serious attitude towards the depiction of laughing due to the bans of Christian doctrines. Following this, it is seen that individuals who commissioned a painting demanded to be depicted in serious-looking postures that can represent their wealth and social status, since a loud laugh showing teeth is believed to demote social status. However, different from other kinds of Western art in 17th century Dutch art, peasants and the poor laughing with showing teeth are depicted. The aim of this paper is to present how new artistic styles flourished in 17th century Holland after Protestantism express the ironic state of laughing and laughter. Therefore, this paper examines the historical process of the act of laughing through a socio-cultural analysis and as a result it denotes the place of the act of laughing in art.
\end{abstract}




\section{Giriş}

'Ne mutlu şimdi ağlayanlarınıza, çünkü güleceksiniz.' diyen Büyük Gregorius'un belirttiği gibi, gerçek, neşe dolu gülme yalnızca cennette yaşanabilir, ama bu cennet sevinci asla gürültülü bir kahkahaya dönüşmez (Sanders, 2001: 165). Böylelikle cennet bile kahkahanın sesinden rahatsız olur.

Gülümsemenin karşı konulmaz bedensel patlamaya dönüşmüş hali olarak tanımlanabilecek gülme, keyif halinin en taşkın ve gürültülü biçimidir. Gülme eylemi, hazdan gelen dürtüsünden dolayı, insanlık tarihi boyunca denetim altına alınması gereken sosyolojik bir sorun alanı oluşturmuştur. Çünkü, karşısına aldığı otoriteye karşı baskın bir yaptırım gücü vardır. İktidarın kendini kabul ettirme, itaat, boyun eğdirme, korkutma gibi toplumu baskı veya kontrol altına alma gibi istekleri sayesinde ciddiyet yaşamın her alanına sokulmaya çalışılmıştır. Gülme eylemi ise, ciddiyet gerektiren otoritenin tam karşısındadır. Bu nedenle otoriter yapı, insan davranışlarını zaman ve mekânlar ile birlikte belirli kalıplara sokmuştur. Bireyin toplumsal saygınlığı ve statüsü ile ilişkilendirilen davranış biçimleri, ciddiyeti gerekli kılmıştır. Bu doğrultuda gülme eylemi, öğretilerin ve yaptırımların izin verdiği ölçüde kabul edilebilir olmuştur. Uygun bulunan ortam ve zamanların dışında gerçekleştirildiğinde ise, toplumsal ayıplanma, dışlanma gibi ahlaki durumlar yaratmıştır. Ar ve edep gibi kavramlarla tanımlanan toplumsal yaptırımlar, gülmenin dozunu, mekânını ve zamanını belirleyen en önemli etmenlerdir.

Toplumsal farklılıklar gösteren ahlaki yapı, toplumun inanç, din ve toplumsal hiyerarşisinin yaptırımlarıyla oluşmuştur. Bunun yanında, ahlaki yapı, güç ve iktidarı ele geçiren sisteme bağlı kalarak da şekil almıştır. Toplumsal dinamiklerinin değişkenliğine rağmen, tarih boyunca dinlerin toplum üzerindeki gücü ise, doğrudan veya dolaylı yoldan da olsa değişmeyen tek unsurdur. Çağlar boyunca çok tanrılı ve tek tanrılı dinlerde gülmenin yarattığı etki ise, ona gösterilen anlayış ve sınırlarla farklılıklar göstermiştir. ilkçağ öncesinde gülme, tanrısal bir boyuttadır ve de insani boyutundan bağımsız bir inanışa dönüşmüştür. Diḡer bir yönüyle, tek tanrılı dinler ile ağırbaşııı̆ına kavuşan tanrı, tarih öncesinde kahkahaları ile evreni yaratmıştır. Mısır'ın ilk tanrısı kabul edilen Re-Atum, Kaosla yüzleşerek, onu kahkahasıyla yenilgiye uğratır. 'Tanrı güldüğünde, dünyaya hükmedecek yedi tanrı dünyaya geldi. Kahkahaya boğulduğunda ışık oldu. İkinci kez kahkahaya boğulduğunda sular oluştu; yedinci kahkahasında ruh doğdu (Sanders, 2001: 17).

Kahkaha ve nefes, eski Mısırlılar da olduğu gibi Budizm'de de önemli bir yer tutmaktadır. İnanışa göre, gülen şişman Buda, cüssesinin ağırlığını kahkaha atarak hafifletir ve kahkahanın dozu yükseldikçe Buda'nın ağırlığı kaybolur. Kahkahalar sayesinde göğe yani en üst noktaya yükselir. Antik Yunan'da ise Olympos'taki tanrılar ile yeryüzündekiler arasında bir köprü niteliğinde olan kahkaha, otoritenin kendini göstermesi gerektiğinde ciddiyetine kavuşur (Sanders, 2001: 111)

Platon, 'Devlet'inde, gülme eyleminin kamusal denetimin sağlanması açısından kontrol altında tutulması gerektiğini savunur ve bunun gerekçelerini ortaya koyar. Gülme eyleminin gücünün farkında olan Platon, gülmeyi, yerleşik düzeni bozguna uğratacak bir tehlike olarak görmektedir. Aristoteles de Platon'un izinden giderek, gülme eyleminin sınırlandırılması gerektiğini savunup, gülmenin toplumda yaratacağı etkileri etik değerler üzerinden ele alarak, görgügörgüsüzlük çerçevesinde deḡerlendirmiştir. Bunun bir yolu olarak da gülme eyleminin, komedyalarla kontrol altına alınmasını önermiştir. Gülme, Roma döneminde Cicero'nun çağında ise, mizahın, zekâyla birleşen nükteli söz söyleme sanatına dönüşmüştür. Kısacası Antik dönem, gülmenin yarattığı gücü inkâr etmemiştir. Onu ıslah ederek, insan davranışlarına hükmetmeye çalışmıştır. Tek tanrılı dinler ise gülmeyi tamamen ortadan kaldırmayı istemişlerdir. Özellikle Hıristiyanlıkla birlikte gülme, İsa'nın çektiḡi çileye hakaret olarak kabul edilip, tanrıdan uzaklaşma olarak algılanmıştır. Sanders'a (2001: 164) göre, Hıristiyan Ortaçağ bağlamında gülme, her zaman 'kirli gülme'dir, mizah her zaman dünyevi mizahtır. İsa'nın hiçbir zaman gülmediğine inanan Hıristiyan inancının kaynağı, gülen bir İsa'nın asla ciddiye alınmayacağı görüşünün yanı sıra gülme eylemi sonucu çıkan eğlenceli sesler arasında, kulların duaları duyulmayabilir ve kurtarıcının onları umursamadığı düşünülebilirdi. Ayrıca, gülme ile 
gelebilecek alaycı tavır da, kilisenin yaptırımlarına ket vurabilirdi. Ciddi, çileci ve acıyı içinde hissedip inanan bir topluma vaat edilecek en iyi şey mutluluk ve huzurdur. Bu inanış da, neşeli ve mutlu bir topluma vaat edilebileceklerinden daha cazip bir durum yaratmaktadır.

Ortaçağ Kilisesi İsa’nın acısına saygı duyarak acı çekmeyi ve her türlü dünyevi zevkten mahrum kalmayı, inanmanın birinci şartı olarak gösterirken, gülmeyi yasaklayarak kontrolü eline geçirmiştir ve dolayısıyla Hıristiyanlığın İsa için betimlediği acı çeken ifadeler, kilise duvarlarındaki resimlerle bir tür öğretiye dönüşmüştür. Böylelikle, dini konulu resimlerin ciddiyeti, halk arasında kilisenin otoritesini de sağlama almış oluyordu. İsa’nın insanlığın kurtuluşu için çektiği ıstırabın karşııında ağlayan Meryem ve aziz betimlemeleri, bulunduğu ortamı hüzün ve acı içerisinde bırakmayı hedeflemiştir ve kilise en ufak keyif verici taşkınlığı asaletten yoksun alt tabaka sınıfın bir tavrı olarak kabul edip, onu yasaklamıştır. Böylelikle soylu ve kentli sınıf, asaletini ancak gülme eylemini kontrol altında tuttuğunda gösterebilmiş oluyordu. Kabul edilemeyen tavırlara sahip köylüyü kentliden ayıran da bu durumda, fakirliğinin yanı sıra gülme eyleminin kontrolsüzlüğüydü. "Başlangıçtan beri, kilise gülmeye kesinlikle karşı olmuştur. Sonuçta, aşağı tabakadan köylüler tanrı kelamından korktukları kadar alaycı gülmeden de korkmayı öğrenebilirlerdi. Ya da daha kötüsü, örgütlenip kendi alaycı saldırılarını gerçekleştirir ve kendilerini tanrı kadar güçlü hissedebilirlerdi. Onur kırııı gülme her köylüyü kendinden menkul bir hayduta dönüştürebilirdi" (Sanders, 2001: 91). Aslında kilisenin korktuğu, gülmenin keyif verici halinden ziyade, onun alaycı tavrındaki yıkııılığıdır. Gülmeye neden olabilecek komik bir durumun yaratacağı etki, acizliğe, zayıflı̆a ve de kontrolsüz davranışlara yol açacağı gibi, otoritenin kontrolünü de bozacaktır. Bu sebeple, komik olanın acıya dönüşmesi Hıristiyanlık için zorunluluk olmuştur.

Ortaçağ boyunca dine hizmet eden Batı Sanatı, Rönesans'la birlikte yeni sanat alıcılarının oluşmaya başlamasıyla, tanrısalıı̆ından çıkıp dünyevileşmeye başlamıştır. Fakat, bu yönüyle de toplumsal davranış biçimlerinin ötesine geçemeyen sanat, soylu sınıfın asaletini, alt tabakadan ayırmak için, yine sanatına bir ciddiyet getirmek zorunda kalmıştır. Dolayısıyla sipariş üzerine gelişen sanat da ciddiyetini müşterilerinin isteklerinden almıştır. Dini konulu resimlerin azaplı ifadelerinin karşısında, saraylı ve burjuva için yapılan portrelerde, birkaç istisnai durum dışında, gülümsemeden eser yoktur. Portrelerin yapılma amaçlarına bakıldığında, bireylerin sosyal statüsünün gösterilmesinin yanı sıra, gelecek nesillere bırakılması gereken saygınlık, yüzlere yansıyan ifadenin gururlu duruşuyla sağlanmaya çalışıımıştır. Sonuçta, bireyin toplum tarafından kabul edilişi ve asaletinin göstergesi, dönemin algııı bağlamında dini dayatmaların ve yaptırımların temellendirildiği ciddiyeti birinci koşul haline getirmiştir. Diğer yönden, Avrupa genelinde Rönesans dönemi boyunca dini konulu resimlerin ve portrelerin dışında cinsel içerikli birçok mitolojik konulu resimler yapılmıştır. Çoğunluğu Güney İtalya resimlerinde görülen bu mitolojik karakterlerin ifadelerindeki gülümsemeler ise, gülme eylemini tanrılara özgü bir davranışa dönüştürerek idealize edilmiş bedenleri yaşamdan uzaklaştırmıştır. Dünyevi bir neşeden uzak bu mitolojik karakterler, sadece gülümsemenin baştan çıkartıcı ve mahrem yönünü temsil etmişlerdir ve kendi içinde yine de bir ciddiyet barındırmıştır (Corbin, Courtine, Vigarello, 2008: 345, 351).

Tarih boyunca toplumun sosyo-ekonomik-politik yapısıyla paralel şekillenen sanat, yeniçağın ardarda getirdiği yeni oluşumları da kendi alanı üzerinden görünür kılmıştır. Bu açıdan bakıldığında, 16. yüzyıldaki değişimlerin en önemlisi sayılabilecek Protestanlığın kabul edilişi, özellikle kuzey Avrupa'da etkili olmuştur ve sonucunda ortaya çıkan yüzyıl savaşları, dinin toplum üzerindeki etkisini tamamen değiştirmiştir. Bu durumdan en çok etkilenen de sanat alanı olmuştur ve sanatçılar yeni arayışlar içerisine girmek zorunda bırakılmıştır. Bunun sonucunda da, Katolik mezhebinin sanata verdiği destek Protestanlıkta kabul görmeyince, sanatçılar din dışı konulara yönelip yeni sanat türlerini yaratmışlardır. Fakat, burada önemli olan diğer bir nokta, Protestan kilisesinin sanat karşıtı tavrına karşın, sanatın yeni destekçilerinin oluşmasıdır. Bu destekçiler de, ruhban ve saraylı sınıfının dışında, çoğunluğu tüccarlardan oluşan kentli soylulardır (Çeler, 2012: 75). 
Protestanlıkla beraber, Avrupa'nın özellikle deniz aşırı ticaretle uğraşan ülkelerinde zenginleşen ve kentli sınıfı oluşturan burjuva, ruhban sınıfının gücünü kendi çıkarları doğrultusunda yönlendirebilmiştir. 17. yüzyıla gelindiğinde ise, özellikle Hollanda sosyal yaşamını etkileyen ve yönlendiren büyük bir güce erişmiştir. Fakat, tek başına ticaret ve zenginlik burjuvanın toplumsal sınıfını kabul ettirmeye yetemezdi. Dinin her ne kadar etkisi deḡişse de yaptırımları değişmemiştir. Martin Luther'den sonra Kalvinizmin öğretileriyle desteklenen burjuva, böylelikle sınıfsal üstünlüğünü paranın verdiği güçle, tanrı katında kabul ettirmiş oluyordu (Tanilli, 1992: 119-124).

Kalvinizm, inancı ruhban sınıfını tekelinden çıkartıp zenginlerin menfaatlerine bırakmıştır. Bu doğrultuda oluşan yeni burjuva ahlakı, zenginliği yücelten bir yapı içinde şekillenmiştir. Zenginliğin tanrısal kurtuluşun işareti sayıldığı bir toplumda da, fakir insanların davranışları ve kahkahalarının tasvip edilebilmesi olası görülmemekteydi:

Maddi rahatlık, seçkinlerden olmanın bir işareti olmak gerekir, yoksulluk da lanete uğramışlığın. Bir başka deyişle, Calvinciliḡin vaaz ettiği dindarlık, mümini, dünya işlerinden ayırmıyordu; tersine, insanın yeryüzünde gerçekleştirebileceği her türlü girişim, 'görev’i oluyor, Tanrı́nın yüceliğine bağlılık eylemine dönüşüyordu. Yükselen burjuvazinin, Calvinci öğretiyi, kazanç amacıyla yaptığı tüm şiddet ve gaspların dinsel yaptırımı olarak görmesi pek doğaldır. Calvincilik, kapitalist birikim uğrundaki her türlü alçaklık ve namussuzluğu olduğu kadar, yoksullara karşı horlamayı ve zalimliği de kutsallaştırıyordu. Calvinci kilise, yeni burjuva ahlakını temsil ediyordu. (Tanilli, 1992: 123)

Kalvinci inanışa göre fakirlik, tanrının lanetlediği bir durumdu. Tanrının sevdiği kullar ise maddiyatı kuvvetli bireylerdi. Kalvincilik ruhban sınıfını ve onların üstünlüğünü ortadan kaldırmıştı fakat yeni oluşan zengin sınıf ile fakir sınıf arasında tanrısal bir sınıf yaratmıştı.

Oluşan bu yeni sınıfın sanattan beklentileri de farklıydı. Kalvinizmin getirdiği yasaklar sonucu, dini konulu resimlerin yerini yaşamdan sahneler almaya başlamıştı. Bu bağlamda, 17. yüzyıl Hollanda sanatı, ruhban sınıfının desteklediği diğer Avrupa ülkelerinin sanatından farklı bir gelişme göstermiştir Burjuva sınıfının beğenileri ve beklentileri, sanatçılara yeni özgürlük alanları açmıştır. Manzara, iç mekân ve gündelik yaşam resimleri gibi diğer Avrupa ülkelerinde sık rastlanmayan yeni sanat türleri oluşmuştur. "Özellikle 16. yüzyılın sonlarında ortaya çıkan ve 17. yüzyıl ortalarında en yetkin örneklerine rastlanan tür resmi, Hollanda toplumunun söz konusu tarihsel dönemdeki siyasi, kültürel, iktisadi ve toplumsal yapısının, bu yapının geçirdiği dönüşümlerin ve özellikle de günlük hayatın yansıdığı bir ayna olarak nitelenebilir" (Çeler, 2012: 73).

Burjuvanın sanata verdiği destek sonucunda Hollanda Sanatı hızla gelişmiştir. Sanata duyulan merak ve ilginin bireyleri ayrıcalıklı bir sınıfa dâhil ettiği düşünüldüğünden dolayı, sanat alanı, burjuva ile saraylı soylular arasında bir üstünlük savaşına dönüşmüştür. Bu doğrultuda hızla gelişen portre sanatı, burjuvanın, fakir köylü görünümünden farkını ortaya koyması açısından, Avrupa geleneḡinin öğretilerine dayanarak ciddiyetini korumak istemiştir. Buna karşın, fakir halkın dişlerini gösteren gülen resimlerinin ortaya çıkması, aradaki sınıfsal farklılığı vurgulamak adına yapılmış olduğunun işareti gibidir. Bugünün gözüyle bakıldığında, toplumsal gerçekçi bir tavırla yapıldığı düşünülen bu tür resimler, halkın eğlenceli dünyasının yanında fakirliğini ve sefaletini ortaya koyan ironik bir durumu ortaya koyar. Fakat, bu tür resimlerin alıcılarını düşünüldüğünde, kendini şanslı hissetmenin Calvinci tutumundan kaynaklandığı anlaşılmaktadır. Çünkü, dişlerin görünmesine izin verecek kadar kendinden geçerek gülme ya da sırıtma, ancak kendinden geçip davranışlarının kontrolünü sağlayamayan köylülere ait bir davranış olabilirdi. Yoksullar, kaba köylüler ve çocuklar, kontrol edilmesi güç olan alt sınıf Kalvinci vicdandan yoksundurlar.

Yoksul insanlar bunlar, yoksullar da sokak ya da köylerde görülür. Oysa bir evin içinde gösterilen yoksullar insana güven duygusu verir. Bu resimlerdeki yoksullar sattıkları şeyleri sunarken gülümsüyorlar (Dişleri görünecek biçimde gülümsüyorlar; resimlerde zenginler hiç böyle gülümse- 
mezler.) Varlıklılara gülümsüyorlar-kendilerini onlara kabul ettirmek, aynı zamanda satmak için ya da bir iş çıkarmak umuduyla gülümsüyorlar. Böylesi resimler iki şeyi bir arada söyler. Yoksullar mutludurlar; varlıklılar dünya için bir umut kaynağıdır. (Berger, 2005: 103)

Ciddiyetteki inandırıcılığın tersine gülme eylemi, alaycılığın ve İsa'nın acısını hiçe saymanın göstergesidir ve burjuvanın meşrutiyeti için şekillenmiş Kalvinizme göre yoksulluğun tanrının katında cezalandırması gerekmektedir. Çünkü, onlar Tanrı istediḡi için yoksuldular ve tanrıyı hiçe sayıp güldükleri için bedel ödemektedirler. Tabi ki bu durum toplumun görünen yüzüdür. Gülme eyleminin, sadece yoksullara ait bir eylem olması düşünülebilir veya kabul edilebilir bir bakış açısı değildir. Toplumsal baskı mekanizması işlemesine rağmen, tamamen ruhsal bir durum olabilecek gülmenin ya da kahkahanın birey üzerinde yarattığı engellenemez patlama, toplumsal alt yapıda bastırılmış bir durumu yaratmıştır ve underground mizah denilen gizli mizahı ve ahlaki durumları da beraberinde getirmiştir.

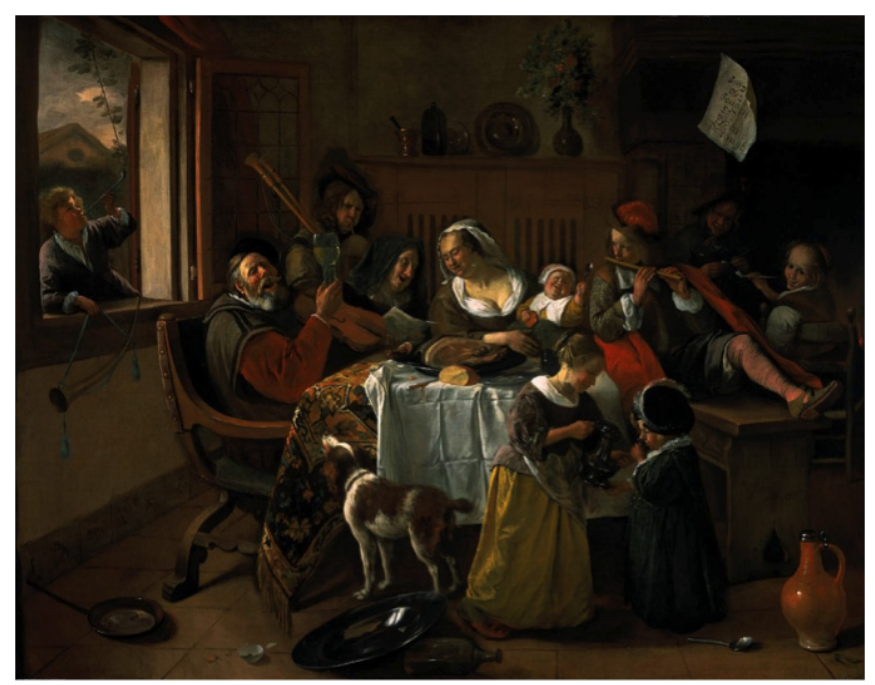

Resim 1. Jan van Steen “Merry Family” 110.5 x 141 cm, 1668.

Jan van Steen'in resimleri (örneğin Resim 1) bu anlamda toplumun ahlaki yapısına ve ikiyüzlülüğüne getirilen eleştiri niteliḡindedir. Ciddiyetten yoksunluğun, gülme ile başlayan ve ahlaksızlığa varan bu resimlerin konuları, kent soylunun duvarlarında bir tür ahlak dersine dönüşmektedir. 17. yüzyıl Hollandası'nda Protestan kiliselerdeki resim yasağına rağmen, din dışı her türlü meslek gruplarına mensup bireyler- den resim siparişi gelebilmekteydi. Resimlerin boyutları da bütçelerin doğrultusunda, belirlenmekteydi. Esnaf ve orta sınıf bile sanat eserine sahip olma konusunda meraklıydı. Bu nedenle küçük boyutlu resimler Flaman sanatında sıkça tercih ediliyordu. Bu kadar geniş bir alıcı kesimin oluşması, sanata olan beklentinin ve işlevinin deḡişmesine neden olmuştur. Buna bağlı gelişen portre sanatı da, ifadelerde içsel bir durumu yakalamak istercesine yumuşamaya başlamıştır (Gombrich, 2011: 413, 433).

Hollanda'nın diḡer Avrupa ülkelerinden farklı bir sınıfsal yapıya sahip olması ve geçirgen toplumsal yapısı, sanattaki ciddiyeti, gündelik yaşama indirgeyebilecek kadar yumuşatan, geniş bir bakış açısına dönüştürmüştür. Hollanda bu bağlamda, "imgeler ve iktisadi sistem, ideolojik-dini düzen ile siyasal mücadeleler gibi toplumsal yapılar arasındaki ilişkilerin iç içe geçmişliğinin en bariz şekilde gözlemlendiği toplumlardan biri olarak değerlendirilebilir." (Çeler, 2012: 73). Bu açıdan bakıldığında, Frans Hals'ın portreleri, Hollanda'nın kültürel çeşitliliğinin en iyi temsilleri gibidir. Hals'ın portreleri, Rönesans'ın idealize edilmiş güzellik anlayışından uzak bir bakış açısıyla, optik gözlemler sonucu, hızlı fırça darbeleriyle oluşturulmuştur (Turani, 1992: 478). Sanatçının yakalamak istediği anlık gülümseme ya da kahkaha (Resim 2 ve 3), mimiklerin yakalanmasındaki zorluklar açısından sanatçıyı döneminin klasik üsluplarının dışına çıkartmıştır. Falcı kadın, çingene kızı, müzisyenler gibi, alt tabakanın dışında, sipariş ile portresini yaptıran burjuva sınıfına ait müşterilerinin bile ciddiyetini bozmuştur.

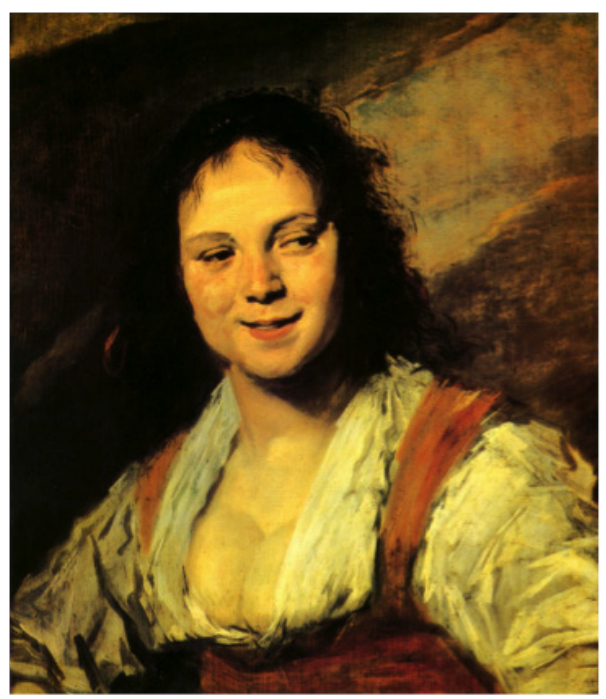

Resim 2. Frans Hals “Gypys Girl, $58 \times 52$ cm, 1628. 


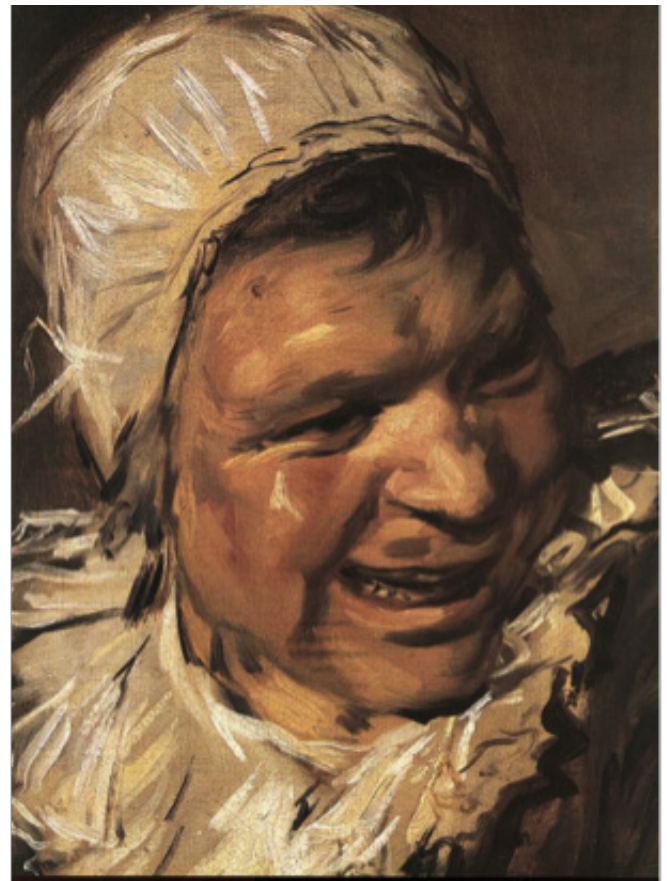

Resim 3. Frans Hals "Malle Babbe" $75 \times 64$ cm, 1630.

Din dışı konuların çeşidi arttıkça, toplumsal içerikli resimlerin ele alınış biçimleri de değişmeye başlanmıştır. Karnaval, düğün, meyhane gibi halkın eğlencelerini konu alan resimler arasında bile anlam farklıı̆ı ortaya çıkmıştır. Fakirliḡin teşhiri yapııdığı kadar, dine karşı bir durumu eleştiren tavır da gelişmiştir. Burada önemli olan, ele alınan ahlaki duruma, nereden bakıldığıyla ilgilidir. 17. yüzyıl Hollanda toplumunun zengin ve özgürlükçü sosyo-kültürel yapısı, görsel kültürün oluşmasında ve anlam çeşitliğinin kazanılmasında birinci faktördür. Sanatın gelişmesine olanak sağlayan zengin kentli, Kalvinizmin desteklediği burjuva ahlakını, sanatın onlara sağladığı olanaklar ölçüsünde görünür kılmıştır ya da tersi bir durum yaratıp eleştirmiştir (Burke, 2003:100-154).

Adriaen Brouwer'in resimlerinde tam da bu noktadan bakıldığında, Jan van Steen, Peter Bruegel'in eğlence, karnaval, düşük yaşam diye nitelenen alt sınıf resimlerinin verdiği ahlak dersinin dışında farklı bir gerçeklik yatar. Ortalama iki yüz elli yıl sonra, tıpkı Lautrec'in "benim gerçek ailem" dediği Paris gece hayatının iç yüzünü resmetmesi gibi, Brouwer de gündelik yaşamın içine dalmış ve onlardan biriymişçesine meyhaneleri ve bu meyhanelerdeki in-

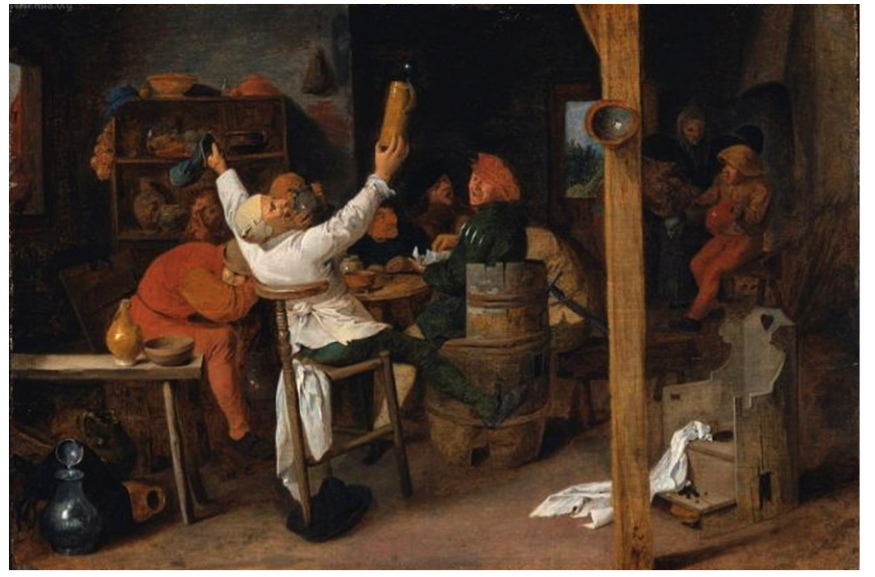

Resim 4. Adriaen Brouwer: "Peasants Carousing in a Tavern" $33.3 \times 49.2 \mathrm{~cm}, 1630$.

sanları resmetmiştir (Turani, 1992: 470). Brouwer, yüzlerdeki anlık ifadeyi yakalamak için hızlıca kullandığı fırçasından yansıyan kahkahalar ve mimikler, ahlak dersi vermez acıyı ya da hissedilen sefaleti Kalvin'e rağmen tüm gerçekliḡiyle ortaya döker. Sefil köylülerin yaşantılarını, eğlencelerini, meyhanelerini resmederken, dine karşı bir mücadeleye girmiştir. Genç yaşta sefalet içinde ölen sanatçının resimlerini onun yeteneğini keşfetmiş olan Rubens'den başkası satın almamıştır (Berger, 2005: 103). Brouwer, Frans Hals'ın yanında yetişmiştir. Portre sanatına yeni bir anlayış getiren Hals, her sınıftan halkın resmini yapmıştır. Anlık mimik hareketleri hızlı fırça vuruşuyla resmeden Hals' in portreleri yaşama dair neşeli izler taşımaktadır. Brouwer de ustasından izinden gitmiştir, fakat yalnızca kendisinin de içinde olduğu dünyanın resimlerini yapmıştır. Burjuvanın ve soylu sınıfın küçümsedikleri yaşam tarzları (Resim 4 ve 5), Brouwer'in sanatının temelini oluşturmuştur (Berger, 2005: 103).

Rembrandt ise 17. yüzyıl Hollandası'nın en ünlü sanatçılarından biri olarak kabul edilir. Sanatçı birçok kere farklı dönemlerde kendi portresini çalışmıştır. Konu bağlamında Rembrandt'ın 'Saskıa'yla Birlikte Kendi Portresi' incelendiğinde, gülümsüyor olmasının Berger tarafından samimi bulunmaması da ayrı bir eleştiri alanı yaratmaktadır. Bu resimde sanatçı, neşe ve saadetin betimlemesini yapmak istemiştir. Karısıyla birlikte en keyifli olabileceğini düşündüğ̈̈ pozu, kameraya bakma doğallığında yakalamak istemiş̧tir. Maddi açıdan o dönem için bir sıkıntısı bulunmayan sanat- 


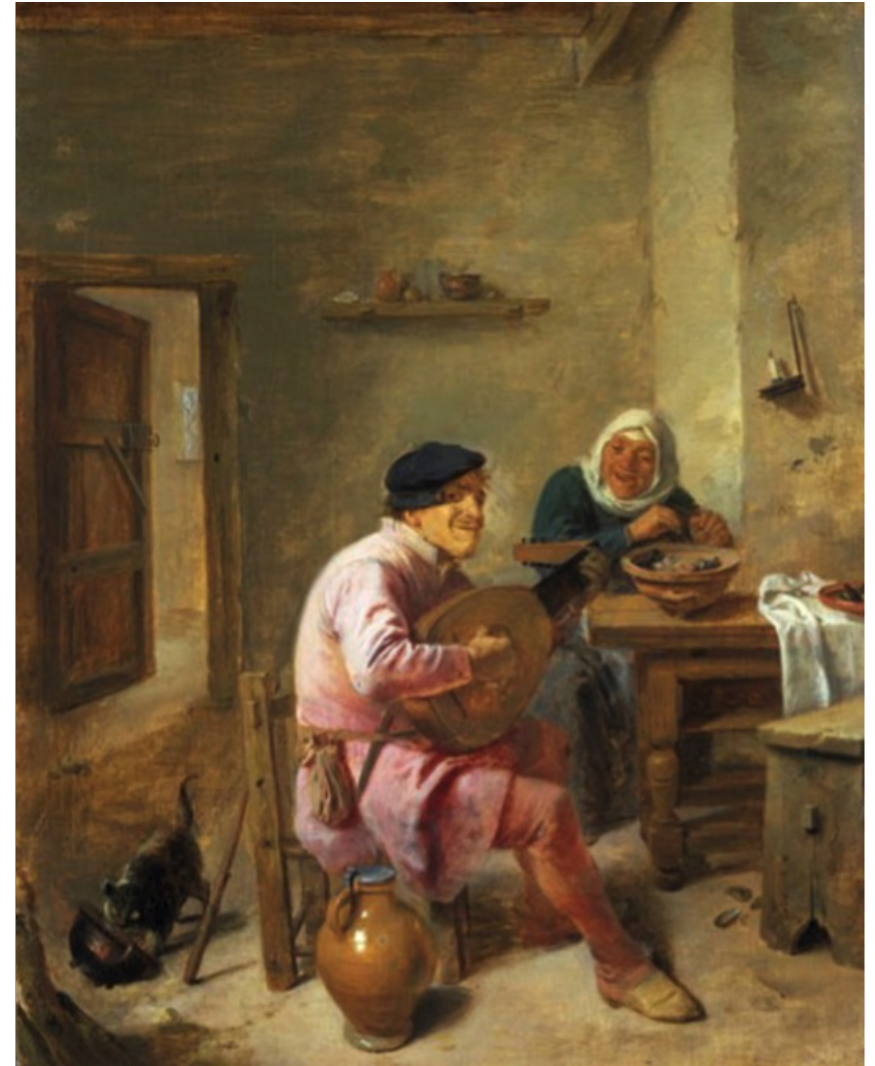

Resim 5. Adriaen Brouwer "Ut Çalan Adam ve Bir Kadın" $37 \times 29.2 \mathrm{~cm}, 1635-38$.

çı, döneminin inanışları gereği ile de Tanrının sevgili kuludur. Dolayısıyla da mutluluğu hak ettiğini düşünmektedir. John Berger (2005: 111) ise, bu resim için "Bütün olarak resim modelin talihliḡini, toplumsal sınıfını, zenginliğini gösteren bir reklamdır" derken eleştirdiği mutluluğun gösterişe dönüşmesindeki rahatsızlığı ifade etmektedir. Sanatçının yaşam standartlarını ortaya koyan bu betimlemede aslında rahatsız eden hiçbir şey yoktur. Sanatçının sonraki yıllarda yapmış olduğu oto portreler, mutluluğunun geçiciliḡini açıkça ortaya koyduğu içindir ki Berger, sanatçının bu resmini samimiyetsiz ve geçici bulmaktadır.

Oysa yüzyıllar sonra fotoğraf makinesine hiçbir sebep olmadan gülümseyen yüzler, mutlu birer anı niteliḡine bürünmektedir ve anıların samimiyeti yıllar sonra izlendiğinde sorgulanmayacaktır. Kahkahanın anlık durumundan olsa gerek, resmedilmesindeki zorluklar, böylesine bir pozun samimiyetini ortadan kaldırır mı diye bir yaklaşım da, zaman kavramındaki an ve geçicilik sorununu beraberinde getirir. Genel itibariyle bakıldığında ise, kahkaha ve gülmenin yer aldığı dönem resimlerinde (Resim 6 ve 7) kullanılan üslupsal yaklaşımlar, kısa süren bu fiziksel patlama anını hızla yakalamak istercesine hızlı fırça darbeleriyle dondurmayı başarabilmişlerdir.

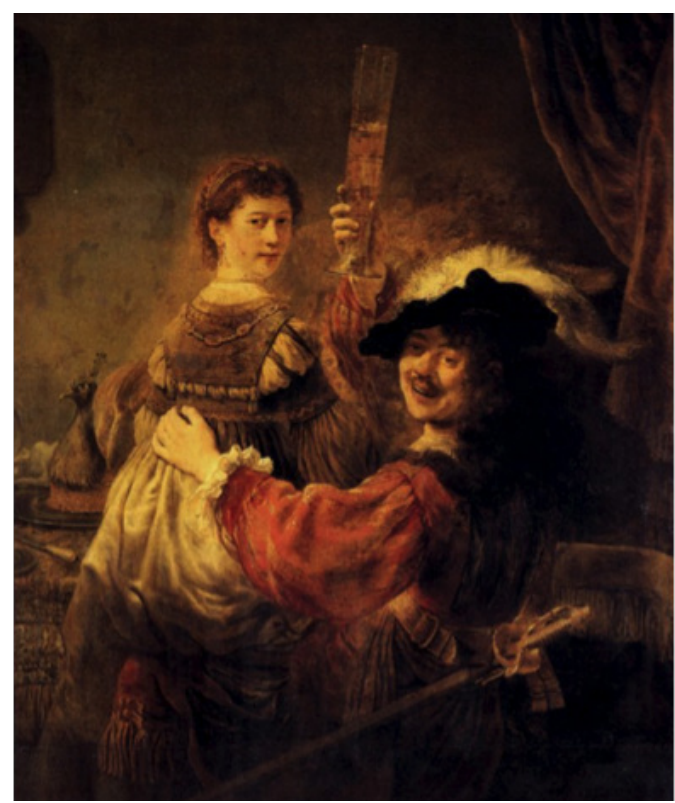

Resim 6. Rembrandt ve Saskia, 131x161 cm,1635

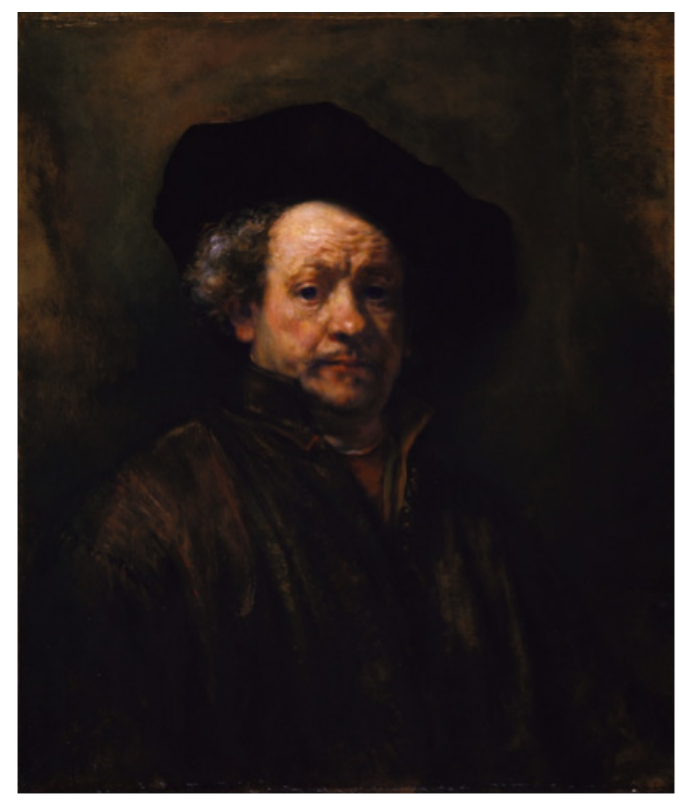

Resim 7. Otoportre, 80,5x67,5 cm, 1660 . 
Molenaer, resimlerinde birçok kere konu edindiği müzisyenleri, neşeli, gülen, yaşamı alaycı tarafından algılayan bireyler olarak betimler. Günümüz bakış açısıyla bu durum, hoşa giden, eğlenceli bir hali tanımlar. Fakat, sanatçının resimlerindeki bu alegorik anlatım, eğlence ve yaşam biçimlerine karşı bir tür eleştiri niteliḡindedir. Festival, karnaval, düğün gibi kahkahanın bol olduğu ve yadırganmayacağı ortamlar, müziğin eşliğinde, batının eski kültürel geleneğini yansıtsa bile, sanatçının eğlence konulu resimlerindeki metaforik anlatım, toplumun bozulmuş yanını açığa çıkartmak amacıyla yapılmıştır. Resimlerdeki figürlerin temsil ettiği birbirinden farklı toplumsal sınıflar ve kostümlerin bir arada kullanımı da bu eleştirinin göstergeleridir. Müzik yapan çocukların kostümlerine bakıldığında, keman çalan çocuğun üstündeki emaneten taşıdığı belli olan burjuva kıyafeti, rommelpot çalan diḡer çocuğun dilencileri anımsatan kıyafeti ve arkadaki küçük kız çocuğun giydiği asker kıyafetiyle bir tür komediyi canlandırıyor gibidirler. "Molenaer'in çocukları bir yandan şarkı söylerken öte yandan biri keman çalıyor (fakat iyi çalamıyor tabii; kemanın sapını nasıl tutacağını bilmiyor), öbürü kaşıklarla miğfere vuruyor." (Leppert, 2002: 241). Resimdeki temsili figürler ile nesnelerin uyuşmazlığı, anlatımı güçlendirmek adına yapılmıştır. Kısacası, bu resimde (Resim 8) ifade edilmek istenen, müziğin sesinin insana kattığı hazdan ziyade, ortaya çıkan gürültü ile aşağı tabakanın sorumsuzluklarını gözler önüne sermektir.

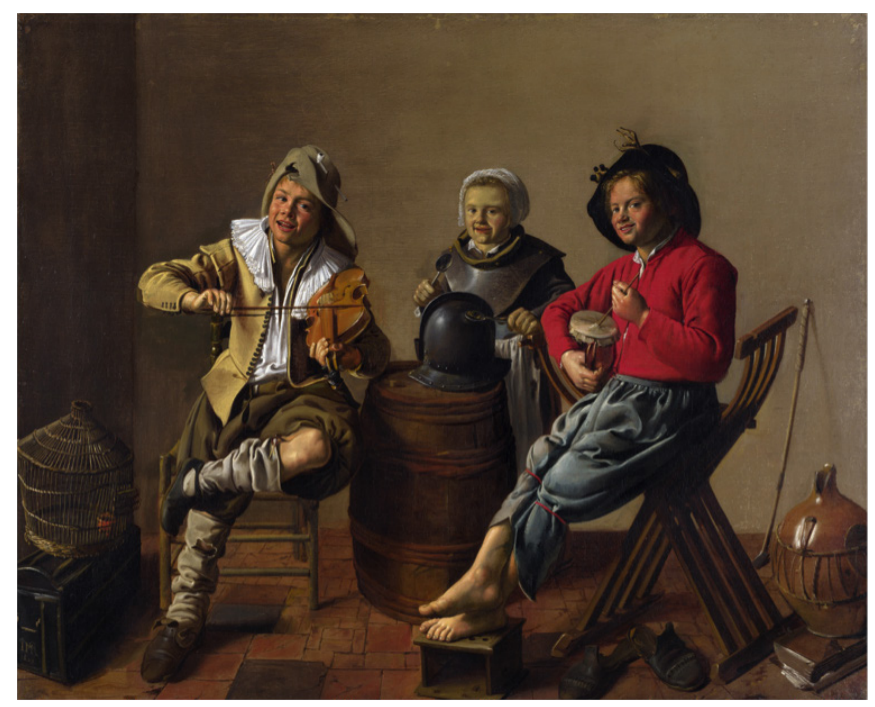

Resim 8. Jan Miense Molenaer, Müzik Yapan Çocuklar, $68.3 \times 84.5 \mathrm{~cm}, 1629$
Bu tarz resimlerin alıcıları, resimleri duvarlarına asıp izlediklerinde, ressamın yaratıcılığından ve yeteneğinden haz alıp keyif duyarlar mıydı bilinmez; ama, evlerine gelen misafirlerine, kendi yaşamlarıyla resimlerde sergilenen yaşam arasındaki farkı göstermek amacını güttüklerini düşünmek ve bu konuda bir yaklaşımda bulunmak, bu araştırma için kaçınılmaz bir hal almıştır.

\section{Sonuç}

Hollanda'nın tür resimlerine karşılık diğer Katolik Avrupa ülkelerinin sanatlarında ciddiyet hiç bozulmadan yüzyıllarca devam etmiştir. Sanatın kendisi de müşterileri kadar ciddiliği sevmiştir. Tarih boyunca, haz, arzu, cinsellik, öfke, şiddet, acı, hüzün gibi insani duyguların temsilleri sanatın sıkça tercih ettiği konulardır. Fakat, bunun yanında mutluluk, keyif, neşe, kahkahanın, sanatın tarihinde bu denli yok sayılması, gösterilmeye çalışıldığında bile onun ahlaki bir eleştiri unsuru olarak kullanılması, sadece toplumsal yaptırımların bir sonucu mudur? Yoksa bir varlık alanı olarak sanatın kendi ciddiyetinden mi kaynaklanmıştır? Sanat alanında ve toplumsal yapıda dinin getirdiḡi yaptırımlar ortadan kalktığında bile, sanat hep ciddi konulara yönelmiştir. Yalnızlaşma, savaşlar, sanayi toplumunun yarattığı etkiler, açlık, kültürel çatışmalar, kimlik sorunları, öteki kavramı gibi sayfalarca çoğaltılabilecek sanatın sıkça ele aldığı konular da ciddiyeti gerekli kılmıştır. Ya da sanatın kendisi başlı başına ciddi bir oluşumdur. Yüzündeki gülümsemesi ile anılan Mona Lisa da, dişlerini göstermekten kaçınmıştır. Tebessümü, nezaket ölçülerinin dışına çıkmamıştır. Gülümsemesi üzerine yazılmış birçok teoriye karşılık, Mona Lisa belki de sanatın bu ciddiyetinin karşısında sessizce ve içinden katıla katıla gülmektedir. 20. yüzyıla gelindiğinde ise Ensor, Grosz, Otto Dix’in resimlerindeki dişleri görünürcesine gülen insanların karşısında izleyici bir gerilim yaşamaktadır. Çünkü, yozlaşmış bir kültürün eleştirel yapısını ortaya koyan bu resimlerin, mutluluktan ya da neşeden kaynaklanmadığı açıkça ortadadır. Gülmenin, tarih boyunca madalyonun iki yüzü gibi iki anlamının olması, bu eylemin en çetrefilli yanını oluşturmuştur. Gülme, birilerinin neşesini yansıtırken, birilerini alay konusu haline dönüştürebilecek bir nispet durumu yaratabilmektedir. Dolayısıyla, gülme eylemi kontrol 
edilmesi gereken tehlikeli bir hal olarak değerlendirilmiştir. Sanat alanı bu paradoksal durumdan uzak kalmayı tercih etmiş ve yüzyıllardır tapınılası bir dokunulmazlıkla ciddiyetini korumuştur. Bunun içindir ki antik mimarinin yüksek sütunlarından geçerek girilen müzelerde, sanat eserlerini izlerken ciddi olunması beklenir. Kutsal bir mekâna dönüştürülen bu müzelerde bir sanat eserinin karşııına geçip, katıla katıla gülmenin sonuçları, toplumca onaylanmayacak bir durumu yaratacaktır. Sanata saygı, ona tapınılası bir durumu yarattığı içindir ki gülme eyleminin toplumsal kontrolü her yerde olduğu gibi sanat eserinin karşısında da geçerliliğini korumaktadır.

\section{Kaynakça}

Berger, John (2005). Görme Biçimleri, çev.: Yıldanur Salman, İstanbul: Metis Yayınları.

Burke, Peter (2003). Sanatın Görgü Tanıkları, çev.: Zeynep Yelçe, istanbul: Kitap Yayınevi.

Celer, Zafer (2012). "17. Yüzyıl Hollanda Toplumu ve Resim Sanatı Üzerine: Bakış, Üslup ve Yorumlama”, ileti-ş-im Dergisi, (16): 73.

Corbin, Alain- Courtine, Jean-Jacques- Vigarello (2008). Bedenin Tarihi I, çev:: Saadet Özen, İstanbul: Yapı Kredi Yayınları.

Gombrich, E. H. (2011). Sanatın Öyküsü, çev.: Erol Erduran-Ömer Erduran, i̇stanbul: Remzi Kitabevi.

Leppert, Richard (2002). Sanatta Anlamın Görüntüsü, çev:: İsmail Türkmen, İstanbul: Ayrıntı Yayınevi.

Sanders, Barry (2001). Kahkahanın Zaferi, çev.: Kemal Atakay, İstanbul: Ayrıntı Yayınları.

Tanilli, Server (1992). Yüzyılların Gerçeği ve Mirası, Cilt III, İstanbul: Cem Yayınları.

Turani, Adnan (1992). Dünya Sanat Tarihi, İstanbul: Remzi Kitabevi.

\section{Görsel kaynaklar}

Resim 1. Jan Steen "Merry Family" 110.5 x 141 cm, 1668.

http://www.wikipaintings.org/en/jan-steen/merryfamily-1668

Resim 2. Frans Hals "Gypys Girl, $58 \times 52$ cm, 1628

http://jahsonic.tumblr.com/post/300230978/gypsy-girl-byfrans-hals-via-upload-wikimedia-org

Resim 3. Frans Hals "Malle Babbe" 75×64 cm, 1630.

http://www.backtoclassics.com/gallery/ franshalsmallebabbe/

Resim 4. Adriaen Brouwer: "Peasants Carousing in a Tavern" $33.3 \times 49.2 \mathrm{~cm}, 1630$.

http://www.terminartors.com/artworkprofile/Brouwer_ Adriaen-Peasants_Carousing_in_a_Tavern
Resim 5. Adriaen Brouwer “Ut Çalan Adam ve Bir Kadın” 37 x 29.2 cm, 1635-38.

http://www.bbc.co.uk/arts/yourpaintings/artists/adriaenbrouwer

Resim 6. Rembrandt ve Saskia, 131x161 cm, 1635-39. http://www.wga.hu/cgibin/search.cgi?author=rembrandt\&tim $\mathrm{e}=$ any \&school $=$ any \&form $=$ any \&type $=$ any $\&$ title $=\&$ comment $=\& l$ ocation $=\&$ from $=160 \&$ max $=20 \&$ format $=5$

Resim 7. Rembrandt Otoportre, 80,5×67,5 cm, 1660.

http://www.hdwallpapersinn.com/rembrandt-vanrijnpictures.html

Resim 8. JanMienseMolenaer,MüzikYapanÇocuklar, $68.3 \times 84.5 \mathrm{~cm}, 1629$. http://www.codart.nl/exhibitions/details/129 